\title{
AKTUALISASI NILAI-NILAI BUDAYA TRADISIONAL DALAM PENGEMBANGAN PARIWISATA DI DAERAH MALUKU
}

\section{Florence Sahusilawane}

Pertama-tama saya menyampaikan terima kasih kepada pihak penyelenggara dari Balai Arkeologi Ambon yang telah mengundang saya terlibat dalam kegiatan diskusi di pagi hari ini. Sesuai dengan tema yang dikemukakan oleh pihak penyelenggara yakni Pengelolaan Warisan Budaya untuk Pengembangan Pariwisata berbasis Kearifan Lokal maka mengacu pada tema yang dikemukakan di atas judul yang saya angkat adalah Aktualisasi Nilai-Nilai Budaya Tradisional bagi Pengembangan Pariwisata di Daerah Maluku.

\section{PENDAHULUAN}

Masih relevankah nilai-nilai budaya tradisional yang adalah warisan nenek moyang kita yang hidup di waktu lampau itu dipakai oleh kita di zaman ini? Hasil karya yang diciptakan di waktu lalu sesuai dengan kebutuhan di masa itu dapatkah terus digunakan di masa modern sekarang ini? Sebuah pertanyaan yang tidak mudah dijawab karena nilai-nilai budaya tradisional itu memiliki unsur-unsur yang berbeda-beda yang tidak selalu sama dengan tuntutan kehidupan di masa kini. Mungkin dengan contoh-contoh kongkrit dalam kehidupan sehari-hari kita dapat membuat sebuah kesimpulan untuk memberikan jawabannya.

Makalah ini mencoba mengemukakan aktualisasi nilai-nilai budaya tradisional dalam kehidupan sehari-hari yang bila ditangani dengan baik merupakan sebuah modal sosial yang dapat dipakai dalah kehidupan masyarakat modern yang majemuk seperti kita di Maluku saat ini yang dapat dimanfaatkan bagi pembangunan dan pengembangan dunia kepariwisataan. Namun mendahuluinya perlu dikemukakan beberapa istilah yang digunakan di sini antara lain aktualisasi, nilai budaya lokal, nilai budaya tradisional sehingga tidak ada kesimpangsiuran dalam diskusi nanti. Aktualisasi berasal dari kata actualization yang dapat diartikan secara sederhana sebagai 
perwujudan; dapat juga diartikan pengaktualan yang kurang lebih artinya membuat sesuatu menjadi nyata atau aktual. Nilai adalah sesuatu yang berharga yang dipedomani untuk dapat menentukan mana yang baik, mana yang tidak baik, mana yang harus ditaati atau mana yang tidak perlu ditaati. Tambahan kata budaya menunjukkan bahwa nilai-nilai itu bersifat kultural atau bersifat budaya hanya ada pada tataran ide atau pengetahuan di belakang kepala saja yang tidak dapat dilihat atau dipegang. Aktualisasi nilai budaya adalah membuat nilai-nilai yang semula tidak dapat dilihat dalam bentuk sikap dan perilaku, tindakan atau dapat dipegang yakni dalam wujud hasil karya benda-benda material. Seseorang yang beriman dan selalu ingat Tuhan aktualisasinya adalah rajin beribadah, rajin memberikan pertolongan kepada orang yang membutuhkan, mengulurkan tangan untuk memberikan sedekah kepada orang lain; sedangkan aktualisasi nilai dalam bentuk benda-budaya material misalnya lukisan, kaligrafi, pakaian, bangunan, dan lain sebagainya.

Nilai budaya tradisional yang dimiliki dari satu generasi ke generasi dalam sebuah komunitas yang hidupnya di suatu tempat yang sama, dalam masa waktu lampau sudah tentu akan jauh lebih mudah dipelihara dan diaktualisasikan oleh kelompoknya bila dibandingkan dengan pemeliharaan serta pengaktualisasian nilai budaya tradisional komunitas yang sama namun hidup di masa sekarang dengan komunitas-komunitas lainnya. Sudah tentu sebuah sikap saling menghargai dan menghormati dalam kemajemukan itu adalah hal utama yang patut diperhatikan. Dirasakan ada nilai-nilai yang sudah tidak sesuai lagi di lain pihak warga pendukungnya masih tetap ingin mempertahankan nilai-nilai budaya itu. Bagaimanapun juga nilai budaya hasil karya leluhur di masa lampau itu dipandang sebagai pedoman dalam hidup yang selama ini mempedomaninya untuk dapat memilih baik dan buruk, boleh atau tidak boleh dan lain sebagainya. Meninggalkan nilai-nilai budaya akan menimbulkan rasa bersalah, rasa menghianati karya leluhur dan perasaan lain sebagainya. Sejalan dengan itu maka sebuah revitalisasi atau reinterpretasi adalah sebuah jalan keluar yang berguna. Dengan demikian pendukung nilai budaya tradisional itu masih dapat memiliki dan memelihara apa yang dimilikinya itu sekaligus dapat eksis sebagai sebuah potensi atau modal budaya yang dapat dipakai dalam melaksanakan pembangunan disegala bidang termasuk di bidang pariwisata.
Satu hal yang selalu harus diingat bahwa hakekat pembangunan serta pengembangan kepariwisataan harus selalu merujuk pada norma agama dan nilai budaya dalam setiap kehidupan manusia; artinya pembangunan kepariwisataan tidak boleh bertentangan dengan agama dan nilai-nilai budaya tradisional yang ada. Semua kekayaan budaya baik yang tangible maupun intangble itu adalah aset berharga yang dapat dimanfaatkan dalam pengembangan pariwisata dimana harus juga dipahami pariwisata adalah alat pelestari kebudayaan yang dapat berperan aktif melestarikan dan memperkenalkan hasil budaya. Pariwisata menempatkan lingkungan alam dan budaya secara inheren. Pariwisata mengedepankan aspek unik, khas, dan kelokalan.

\section{AKTUALISASI NILAI BUDAYA TRADISIONAL DALAM PENGEMBANGAN PARIWISATA}

Maluku memiliki beragam nilai budaya lokal, tradisional baik tangible maupun intangible yang unik, khas sebagai bagian dari karya leluhur di masa lampau yang telah diwariskan dari satu generasi ke generasi berikutnya di mana karya budaya itu masih terus dikembangkan oleh pendukungnya. Sesuai dengan ciri pengembangan kepariwisataan yakni unik, khas, dan kelokalan maka beberapa hasil karya ini bila diaktualisasikan dengan baik akan bermanfaat dalam pengembangan pariwisata (di Maluku).

\section{Arsitektur Tradisional}

Arsitektur yang khas dari sebuah bangunan dari suatu suku bangsa baik rumah tinggal, rumah adat, rumah ibadah serta bangunan rumahrumah lainnya memiliki ragam hias yang unik, yang umumnya dapat menggambarkan identitas dari suku bangsa tersebut. Melalui kajian arsitektur tradisional kita dapat mengetahui peri laku sikap hidup masyarakat seharihari misalnya bagaimana ia dapat berinteraksi dengan sesama, dengan alam serta dengan penciptanya. Selain itu kitapun dapat mengetahui tingkat peradaban dan teknologi yang sedang berkembang di masa itu. Ragam hias bangunan-bangunan tradisional pada satu suku bangsa termasuk lingkungan pemukiman sangat menarik untuk dijadikan objek wisata budaya. Sejalan 
Florence Sahusilawane, Aktualisasi Nilai-Nilai Budaya Tradisional dalam Pengembangan Pariwisata....

dengan itu aktualisasi nilai budaya tolong-menolong, silaturrahmi, toleransi terus dilestarikan dan dikembangkan kepada semua pihak.

\section{Pasar Tradisional}

Pasar merupakan arena pertemuan penjual dan pembeli, pasar tradisional adalah sebuah karya masa lampau. Tempat itu merupakan pusat pertemuan kerabat dan pertemuan budaya antar suku bangsa. Saat ini pasar-pasar tradisional terpinggirkan akibat maraknya pembangunan pusat-pusat perbelanjaan modern; akibatnya tempat-tempat pertemuan tidak resmi yang merupakan arena saling mengeratkan hubungan pertemanan, arena pergunjingan, arena tenggang rasa, yang perlu dilestarikan menjadi menipis atau hilang dan diganti dengan perilaku acuh tak acuh, tidak saling mnegenal dan lain sebagainya. Pasar-pasar tradisional adalah sekaligus tempat untuk menjual produk lokal yang unik, yang khas yang dimiliki oleh suku bangsa atau komunitas tertentu. Bila tidak diperhatikan dengan baik akhirnya akan hilang padahal pasar tradisional itu adalah aset wisata. Kita lihat pasar Sukowati di Bali, pasar Ular di Jakarta, pasar Klewer di Solo, pasar Bringharjo dan Malioboro di Jogjakarta adalah pasar-pasar tradisional yang tetap eksis menyajikan sebuah kehidupan tradisional baik penjualnya, pembelinya, jenis-jenis dagangannya (makanan dan benda khusus) sampai cara berdagangnya sangat menarik sebagai obyek pariwisata. Wisatawan akan senang berbelanja sambil menikmati perilaku orang-orang di pasar.

\section{Upacara Tradisional}

Masyarakat Maluku adalah masyarakat majemuk di mana setiap kelompok suku bangsa memiliki beragam jenis upacara tradisional. Ada upacara-upacara yang sifatnya magis dan ada pula yang profan. Upacaraupacara tradisional adalah ekspresi kehidupan budaya masyarakat. Selama tidak mengurangi dan menggangu nilai kesakralan pada upacara itu maka jenis upacara itu dapat dimanfaatkan untuk objek wisata misalnya upacara panas pela, upacara cuci negeri, upacara buka sasi, buka kampung dan lain sebagainya.
Florence Sahusilawane, Aktualisasi Nilai-Nilai Budaya Tradisional dalam Pengembangan Pariwisata....

\section{Permainan Tradisional}

Permainan adalah hiburan yang biasanya dimainkan oleh anak-anak maupun orang dewasa saat melepas lelah. Dalam berbagai jenis permainan itu sesungguhnya ada pesan-pesan yang ingin disampaikan. Lewat permainan orang dapat saling mengakrabkan diri dan bersosialisasi. Kita kaya dengan berbagai macam permainan yang tidak kalah dengan permainan-permainan modern bahkan permainan-permainan itu tidak memerlukan uang yang banyak untuk memainkannya. Melalui arena lomba atau festifal permainanpermainan tersebut dapat terus dilestarikan dan dikembangkan sebagai objek menarik wisatawan.

\section{Tradisi Lisan}

Tradisi lisan dalam bentuk folklore misalnya, ceritera rakyat, teka-teki tradisional, pantun, musik tradisional, sesungguhnya mengandung banyak nilai bagi pendukungnya. Di dalamnya ada tuturan sejarah, ada nasehat, ada sindiran, kritikan, hiburan dan lain sebagainya.

\section{PENUTUP}

Kebudayaan dan pariwisata adalah sebuah keping mata uang yang bernilai sama tidak dapat dipisahkan. Tanpa ada pemanfaatan hasil kebudayaan dunia kepariwisataan akan menjadi kering dan kerontang serta tidak menarik. Sebaliknya melalui dunia pariwisata pembangunan kebudayaan dapat lestari. Dengan kata lain pengembangan kepariwisataan adalah salah satu cara untuk melestarikan kebudayaan. Tepatlah apa yang dikatakan pariwisata adalah pelestari kebudayaan. Mengakhiri makalah ini tibalah kita pada pertanyaan awal tadi masih relevankah nilai-nilai budaya tradisional yang kita dukung selama ini ? Sebelum memberi sebuah kesimpulan untuk menjawab, perlu dijelaskan bahwa manusia pada dasarnya (1) ingin tetap memiliki dan menggunakan nilai budaya tradisional yang sudah dikenal dengan baik oleh dirinya (2) manusia tetap berusaha agar jangan sampai merasa telah mengkhianati atau meremehkan warisan leluhurnya, (3) manusia tidak mau kehilangan identitas diri. Untuk itu cara yang terbaik adalah melakukakn revitalisasi dan reinterpretasi kembali isi dari perangkat nilai budaya itu. Bila demikian adanya harta kekayaan warisan masa lalu itu tetap harus dilestarikan. 